\title{
PKM Penanganan Stunting Desa Kawunganten Lor Kecamatan Kawunganten Kabupaten Cilacap: Sasaran Keluarga Dengan Anak Stunting
}

\author{
${ }^{1}$ Kasron*, ${ }^{2}$ Susilawati, ${ }^{3}$ Wishnu Subroto \\ ${ }^{1}$ S1 Keperawatan, STIKES Al-Irsyad Al-Islamiyyah Cilacap \\ ${ }^{2}$ S1 Kebidanan, STIKES Al-Irsyad Al-Islamiyyah Cilacap \\ ${ }^{3}$ D3 Fisioterapi, STIKES Al-Irsyad Al-Islamiyyah Cilacap \\ *Penulis korespondensi, email:kasronrw@gmail.com
}

(Received: 23 November 2020/Accepted:18 January 2021/Published: 28 January 2021)

\begin{abstract}
Abstrak
Pentingnya pengabdian masyarakat ini karena angka prevalensi kejadian stunting masih sangat tinggi di Desa Kawunganten Lor Kecamatan Kawunganten Kabupaten Cilacap. Maka dari itulah perlu dilakukan penanganan stunting dengan penyuluhan dan pelatihan pembuatan makanan tambahan olahan berbahan dasar lokal pada anak dan balita. Tujuan pengabdian masyarakat ini adalah untuk meningkatkan derajat kesehatan anak dengan stunting di Desa Kawunganten Lor. Metode pengabdian dilakukan dengan pelatihan, demonstrasi dan kampanye pembuatan olahan makanan tambahan berbahan makanan lokal. Pada pengabdian ini telah berhasil dilakukan penyuluhan pentingnya gizi anak, pelatihan pembuatan olahan makanan berbahan dasar lokal, pemberian makanan tambahan, pelaksanaan pengabdian masyarakat dilakukan diawali dengan pendataan jenis tanaman lokal sumber gizi, kegiatan memperbanyak jumlah tanaman, pelatihan pembuatan olahan makanan tambahan berbahan dasar lokal, pemberian makanan tambahan pabrikan, dan pencatatan konsumsi makanan. Hasil yang diperoleh adalah mitra keluarga dengan anak stunting mampu mengidentifikasi bahan lokal untuk bahan makanan tambahan, mitra mampu memproduksi makanan tambahan. Derajat kesehatan keluarga dengan anak stunting meningkat. Setelah pengabdian ini dilakukan, masyarakat mitra mulai tergerak akan pentingnya kesehatan dan upaya penanganan stunting pada anak.
\end{abstract}

Kata Kunci : Stunting, bahan pangan lokal, suplemen makanan

\begin{abstract}
The importance of community service is because the prevalence rate of stunting is still very high in Kawunganten Lor Village, Kawunganten District, Cilacap Regency. Therefore, it is necessary to handle stunting with counseling and training in making additional processed food made from local ingredients for children and toddlers. The aim of this community service was to improve the health status of children with stunting in Kawunganten Lor Village. The service method is carried out by training, demonstrations and campaigns for making additional food preparations made from local food. In this service, counseling on the importance of child nutrition has been carried out, training in making processed food made from local ingredients, providing additional food, carrying out community service activities starting with data collection on the types of local plant sources of nutrition, activities to increase the number of plants, training in making additional processed food made from local ingredients, provision of supplementary food manufacturers, and recording of food consumption. The results obtained were family partners with stunting children were able to identify local ingredients for additional food ingredients, partners were able to produce additional food. The health status of families with stunted children is increasing. After this service was carried out, the partner community began to be moved by the importance of health and efforts to treat stunting in children.
\end{abstract}

Keywords: Stunting, local food ingredients, dietary supplements 


\section{Pendahuluan}

Pendahuluan Indonesia masih menghadapi permasalahan gizi yang berdampak serius terhadap kualitas sumber daya manusia (SDM). Salah satu masalah gizi yang menjadi perhatian utama saat ini adalah tingginya jumlah anak balita pendek (stunting). Data Pusdatin menunjukan prevalensi stunting Indonesia 2005-2017 mencapai 36,4\%. Prevalensi balita stunting mengalami peningkatan jumlah di tahun 2016 dari $27,5 \%$ menjadi $29,6 \%$ pada tahun 2017 (Kementerian Kesehatan RI, 2018).

Prevalensi stunting di Kabupaten Cilacap sebesar 36,32\% dan Kabupaten Cilacap termasuk dalam 100 Kabupaten dengan prioritas tingkat nasional, dan masuk dalam 11 Kabupaten prioritas tingkat provinsi Jawa Tengah. Diketahui sebanyak 6.647 balita $(5,19 \%)$ di Kabupaten Cilacap mengalami stunting. Salah satu desa dengan kasus stunting tertinggi adalah Desa Kawunganten Lor (Humas Setda Kabupaten Cilacap, 2018). Desa Kawunganten Lor masuk wilayah Kecamatan Kawunganten yang memiliki luas wilayah 333 Ha dengan jumlah penduduk 8.213 jiwa, dimana 6,7 persen tercatat sebagai penduduk kategori miskin. Sebagian besar warga Desa Kawunganten Lor bermata pencaharian sebagai petani dan buruh (Monografi Desa Kawunganten Lor, 2018). Dari hasil penimbangan serentak pada balita seluruh posyandu di wilayah kerja Puskesmas Kawunganten periode Desember 2018 diketahui dari 6.148 anak, terdapat 24 anak pada usia 0-2 tahun mengalami stunting dan 70 anak pada usia 2-5 tahun mengalami stunting di Desa Kawunganten Lor (Laporan Puskesmas Kawunganten, 2018).

Kepala Puskesmas Kawunganten menjelaskan pihak Puskesmas telah melakukan upaya pencegahan dan penanganan stunting di wilayah kerja Puskesmas Kawunganten dengan upaya intervensi kesehatan berbasis komunitas seperti pemberian vitamin A pada bayi dan balita, pemberian obat cacing, pemeriksaan garam tingkat masyarakat posyandu, survailans kasus stunting dan gizi buruk, pemberian makanan tambahan (PMT), kelas ibu hamil, kelas balita, Antenatal Care (ANC) terpadu, pemberian imunisasi, promosi cuci tangan pakai sabun (CTPS) di Sekolah, penyuluhan 1000 hari pertama kelahiran (HPK) pada ibu-ibu usia produktif dan pada ibu hamil-ibu menyusui. Dari upaya-upaya tersebut, masih terjadi kasus stunting di wilayah Puskesmas Kawunganten, yang disebabkan masih rendahnya pengetahuan warga tentang hidup bersih dan sehat dan juga masih rendahnya warga tentang pencegahan stunting pada lini keluarga.

Ketua Kader Kesehatan Desa (KKD) menyebutkan bahwa tingginya angka kejadian stunting di Desa Kawunganten Lor disebabkan masih rendahnya pengetahuan warga tentang pentingnya pemenuhan nutrisi ibu hamil, nutrisi ibu menyusui. Tingginya angka kejadian stunting juga disebabkan karena sebagain besar warga hanya tergantung pada satu bahan makanan pokok beras saja dan belum mampu mengolah bahan makanan lokal desa seperti ubi ungu, ubi jalar, kelor, pisang, ketela, jagung dan tanaman lainnya untuk dibuat makanan pendamping tambahan untuk pemenuhan nutrisi keluarga baik untuk ibu hamil-ibu menyusui.

Dari penjelasan diatas diketahui bahwa penyebab kejadian stunting di wilayah Desa Kawunganten Lor sangat banyak dan sangat kompleks, sehingga perlu penanganan yang terus menerus dan berkelanjutan selama beberapa waktu mendatang supaya memutus rantai kejadian stunting di wilayah Kawungante Lor. Pengabdian masyarakat ini bertujuan untuk mengatasi permasalahan-permasalahan yang menjadi penyebab stunting di wilayah Desa Kawunganten Lor tersebut.

Selanjutnya dengan memperhatikan hasil analisis situasi dan usulan mitra, maka disepakati bersama antara mitra dan tim pengusul tentang fokus permasalahan yang akan diatasi dan dilaksanakan dalam kegiatan Pengabdian Kepada Masyarakat skema Program Kemitraan Masyarakat (PKM) penanganan stunting di Desa Kawunganten Lor dalam tim pengabdian ini salah satunya adalah sebagai berikut: rendahnya pengetahuan warga tentang stunting dan terbatasnya pemenuhan makanan bergizi untuk anak balita dengan stunting. 


\section{Metode}

Metode Selanjutnya dengan memperhatikan hasil analisis situasi dan usulan mitra Kader Kesehatan Desa (KKD), maka ditetapkan metode dalam kegiatan pengabdian (PKM) Penanganan Stunting Desa Kawunganten Lor Kabupaten Cilacap Provinsi Jawa Tengah: pada sasaran keluarga dengan anak balita dengan stunting, dengan tahapan-tahapan sebagai berikut:

1. Survei Awal dan Persiapan

Pada tahap ini dilakukan pendataan tentang topik-topik sebagai berikut:

a. Pendataan tentang jenis tanaman lokal sebagai sumber protein nabati yang berpotensi sebagai bahan pangan lokal untuk dijadikan olahan makanan tambahan.

b. Pendataan jumlah anak dengan stunting.

2. Implementasi

Pada tahap ini diberikan materi-materi tentang pengetahuan dan keterampilan penanganan stunting dengan sasaran keluarga dengan anak balita dengan stunting, dilakukan intervensi sebagai berikut:

a. Penyuluhan, transfer pengetahuan kesehatan dan kampanye tentang stunting, pencegahan, intervensi dan tatalaksana stunting, tentang pentingnya pemberian makanan tambahan (PMT) berbahan dasar lokal untuk anak dan balita secara periodik saat kegiatan posyandu

b. Pelatihan, demonstrasi dan kampanye pembuatan olahan makanan tambahan berbahan makanan lokal yang seimbang sumber protein hewani dan protein nabati untuk anak dan balita dengan stunting

3. Evaluasi Pelaksanaan PKM Dan Keberlanjutan PKM

Evaluasi pelaksanaan dan keberlanjutan pada topik pemenuhan makanan bergizi untuk anak dan balita dengan stunting dilakukan oleh warga, KKD, PKK dan petugas puskesmas setiap bulan saat kegiatan posyandu. Sedangkan keberlanjutan setelah PKM dilakukan olen KKD, PKK dan petugas peskesmas setiap bulan saat kegiatan posyandu.

\section{Hasil dan Pembahasan}

Hasil kegiatan pengabdian pada warga di Desa Kawunganten Lor sebagai berikut:

\subsection{Tahap Awal dan Persiapan}

Pada proses persiapan tim melakukan koordinasi dengan pihak-pihak terkait. Ketua tim berkoordinasi dengan pihak Desa dan untuk melakukan survey awal terhadap kejadian kasus stunting di Desa Kawunganten Lor, sedangkan anggota tim menemui Kader Kesehatan Desa (KKD) untuk kontrak waktu pelaksanaan, dan survei lokasi pelaksanaan.

\subsection{Tahap Survey}

Pada tahap ini tim melakukan kegiatan survey awal ke wilayah-wilayah lokasi khusus (lokus) di daerah dengan kejadian anak stunting yang tinggi diantaranya di RW 1, RW 2, RW 3, RW 4, RW 5, RW 6 secara bersama-sama antara tim Puskesmas dan Tim Pengabdian STIKES Al-Irsyad Al-Islamiyyah Cilacap yang dilakukan tanggal 6 Februari 2020. Dilanjutkan pada tanggal 13 Februari 2020 diskusi dengan tim Puskemas untuk analisa masalah stunting dan perencanaan intervensi di lokus stunting Desa Kawunganten Lor.

\subsection{Tahap Pelaksanaan}

\section{a. Penyuluhan awal tentang Stunting}

Pelatihan tentang stunting awal dilakukan kepada kader yang dilakukan di Kantor Desa Kawunganten Lor dilakukan tanggal 16 Februari 2020. Pada kegiatan ini dihadiri oleh 16 kader dan TIM Pengabdian LPPM Stikes Al-Irsyad AlIslamiyyah Cilacap (Gambar 1). Materi pelatihan tentang pengertian stunting, penyebab stunting, akibat stunting, pencegahan stunting, dan intervensi pada anak dengan stunting dan beberapa instrument intuk pendeteksian anak dengan stunting. 
Dalam kegiatan penyuluhan dilakukan kegiatan evaluasi pretest dan postes untuk mengetahui tingkat pengetahuan warga tentang konsumsi makan pada anak dengan stunting dengan cara memberikan pertanyaan pilihan sederhana yang harus mereka jawab. Terdapat sejumlah 23 pertanyaan dengan menjawab benar atau salah seperti tercantum dalam lampiran. (skor terendah 0 dan tertinggi 23).

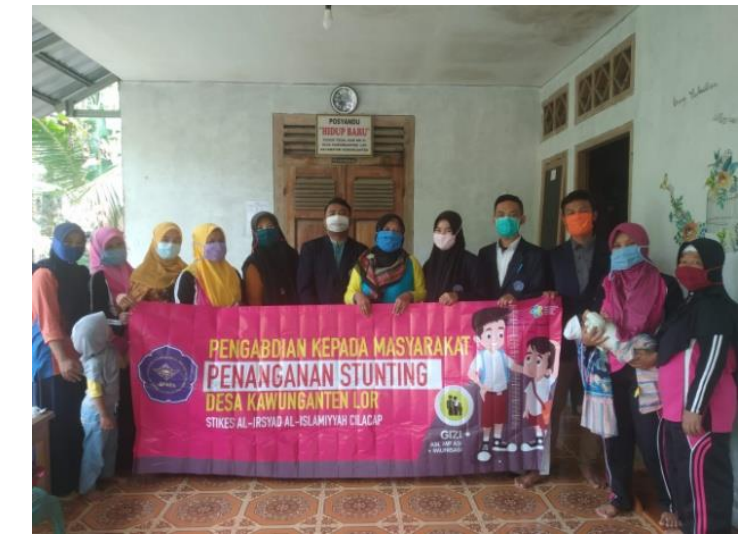

Gambar 1. Kegiatan Penyuluhan dengan Kader

Tabel pengetahuan sebelum dan setelah kegiatan penyuluhan materi pengetahuan tentang stunting oleh para kader tercantum dalam Tabel 1.

Tabel 1. Nilai Pengetahuan Kader Sebelum dan Setelah Pemberian Materi (n=16)

\begin{tabular}{|c|c|c|c|}
\hline Peserta & Tingkat pengeahuan & Sebelum f (\%) & Sesudah f $(\%)$ \\
\hline KKD* & $\begin{array}{c}\text { Tinggi } \\
\text { Rendah }\end{array}$ & $\begin{array}{l}9(56,25) \\
7(43,75)\end{array}$ & $\begin{array}{c}16(100) \\
0(0)\end{array}$ \\
\hline
\end{tabular}

*Ket: KKD: Kader Kesehatan Desa

Dari KKD yang hadir diperoleh bahwa pengetahuan sebelum penyuluhan pada kategori pengetahuan tinggi sebanyak $56,25 \%$, dan setelah penyuluhan pada kategori pengetahuan tinggi sebanyak $100 \%$. Hal tersebut menunjukan dengan kegiatan penyuluhan pada pengabdian kepada masyarakat menunjukan adanya peningkatan pengetahuan kader terhadap materi stunting pada anak.

b. Penyuluhan kepada keluarga binaan dengan anak stunting

Pelatihan tentang stimulasi dan intervensi anak dengan stunting dilakukan kepada keluarga dengan anak stunting di RW 4 pada masing-masing keluarga yang dilakukan. Kegiatan penyuluhan juga dilakukan kepada keluarga dengan stunting, pada kegiatan ini tim pengabdian membina 12 keluarga dengan anak stunting. Nilai pretest dan posttest pengetahuan tentang konsumsi makan pada anak dengan stunting tercantum pada Tabel 2.

Tabel 2. Nilai Pengetahuan Keluarga dengan Anak Stunting Sebelum dan Setelah Pemberian Materi $(\mathbf{n}=12)$

\begin{tabular}{cccc}
\hline Peserta & Tingkat pengeahuan & Sebelum f (\%) & Sesudah f (\%) \\
\hline Keluarga & Tinggi & $5(41,67)$ & $12(100)$ \\
& Rendah & $7(58,33)$ & $0(0)$ \\
\hline
\end{tabular}

Dari keluarga dengan anak stunting diperoleh bahwa pengetahuan sebelum penyuluhan pada kategori pengetahuan tinggi sebanyak 41,67\%, dan setelah penyuluhan pada kategori pengetahuan tinggi sebanyak 100\%. Hal tersebut menunjukan dengan kegiatan penyuluhan menunjukan adanya peningkatan pengetahuan keluarga dengan anak stunting terhadap materi stunting pada anak. 


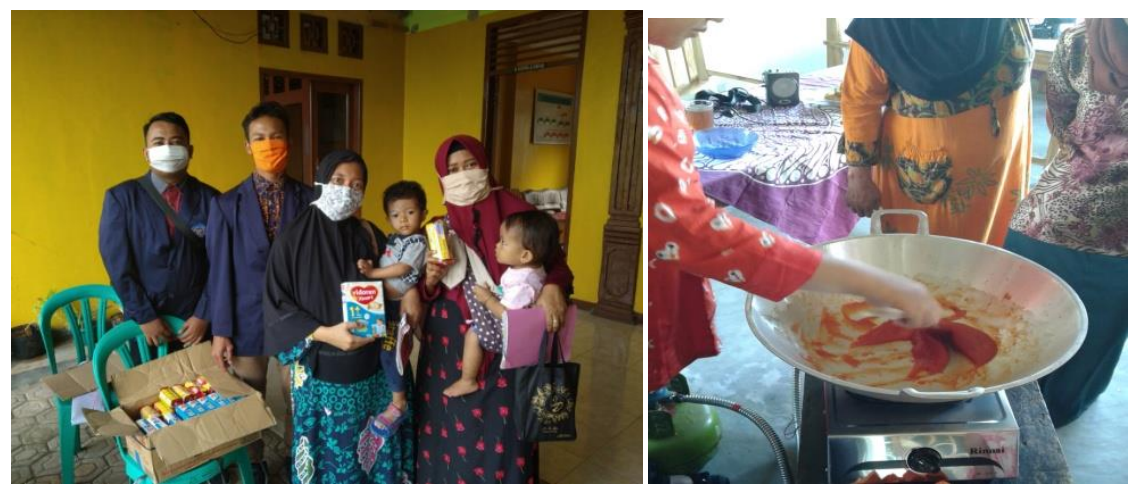

Gambar 2. Kegiatan Penyuluhan dan Pelatihan Pembuatan Makanan Olahan pada Keluarga dengan Anak Stunting

\section{c. Pelatihan praktek}

Kegiatan pelatihan praktek pemberian makanan tambahan berbahan dasar lokal dilaksanakan pada masing-masing keluarga dengan anak stunting yang dilakukaan secara bertahap dengan mengidentifikasi makanan yang tersedia di sekitar pekarangan rumah seperti sumber karbohidrat seperti singkong, ubi, jagung, daun kelor, sedangkan sumber protein dengan memanfaatkan semua jenis ikan air tawar di sekitar wilayah rumah seperti lele, mujaer, bethik dan telor (Gambar 2). Semua bahan tersebut dibuat bubur dan juga makanan ringan untuk dikonsumsi oleh anak dengan stunting. Kegiatan dilakukan mulai bulan Maret 2020 sampai April 2020

Tabel 3. Keterampilan keluarga dengan anak stunting dalam membuat makanan olahan berbahan baku lokal

\begin{tabular}{cccccc}
\hline Sasaran & $\mathbf{N}$ & \multicolumn{2}{c}{ Sebelum f (\%) } & \multicolumn{2}{c}{ Setelah f (\%) } \\
\cline { 2 - 6 } & & $\begin{array}{c}\text { Belum } \\
\text { membuat }\end{array}$ & $\begin{array}{c}\text { Pernah } \\
\text { membuat }\end{array}$ & $\begin{array}{c}\text { Belum } \\
\text { membuat }\end{array}$ & $\begin{array}{c}\text { Pernah } \\
\text { membuat }\end{array}$ \\
\hline $\begin{array}{c}\text { Keluarga Dengan } \\
\text { Anak Stunting }\end{array}$ & 12 & $8(66,67)$ & $4(33,33)$ & $0(0)$ & $12(100)$ \\
\hline
\end{tabular}

Berdasarkan Tabel 3 di atas, dari keluarga dengan anak stunting diperoleh bahwa keterampilan pembuatan makanan olahan berbahan baku lokal sebelum pengabdian sebanyak 33,33\% keluarga pernah membuat makanan olahan berbahan baku lokal, dan setelah pengabdian menunjukan semua keluarga (100\%) dapat membuat makanan olahan berbahan baku lokal.

\subsection{Monitoring}

Kegiatan monitoring dilakukan oleh kader KKD setiap bulan dengan pengecekan pembuatan makanan olahan berbahan dasar lokal saat kegiatan posyandu.

\section{Simpulan}

Kesimpulan kegiatan pengabdian ini adalah setelah dilakukan kegiatan pengabdian kepada masyarakat didapatkan adanya peningkatan pengetahuan KKD dan keluarga dengan anak stunting tentang materi stunting dan keluarga dengan anak stunting dapat membuat makanan olahan berbahan lokal setelah kegiatan pengabdian, Keterampilan kader KKD dan keluarga dengan anak stunting dalam mengolah bahan lokal untuk bahan makanan meningkat.

\section{Persantunan}

Kami mengucapkan terimakasih kepada Deputi Bidang Penguatan Riset dan Pengembangan Kementerian Riset dan Teknologi / Badan Riset dan Inovasi Nasional, Sesuai dengan Kontrak Pengabdian Tahun Anggaran 2020, dan UPT PPM STIKES Al-Irsyad Al-Islamiyyah Cilacap 
yang telah memberikan kesempatan dan support dana dalam pelaksanaan Program Kemitraan Masyarakat (PKM) tahun 2020.

\section{Referensi}

Humas Setda Kabupaten Cilacap. (2018). 10 desa di Cilacap, balitanya alami stunting. Cilacap. Retrieved from https://humas.cilacapkab.go.id/2018/10/05/10-desa-dicilacap-balitanya-alami-stunting/

Kementerian Kesehatan RI. (2018). Situasi Balita Pendek (Stunting) di Indonesia. (Pusdatin, Ed.). Jakarta: Pusat Data dan Informasi Kesehatan.

Laporan Puskesmas Kawunganten. (2018). Laporan Evaluasi Stunting Puskesmas Kawunganten. Cilacap.

Monografi Desa Kawunganten Lor. (2018). Monografi Desa Kawunganten Lor. Cilacap.

C 2021 by the authors. Submitted for possible open access publication under the terms and conditions of the Creative Commons Attribution (CC-BY-NC-ND) license (http://creativecommons.org/licenses/by/4.0/). 